\title{
The Impact of Strategic Planning on the Reform of Lebanese Public Administration
}

Charbel El AMMAR ${ }^{1}$

\begin{abstract}
For Lebanon to reach its future obligations prior to the implementation of "Capital Investment Plan" or what we called "Cedar Project", the need for strategy in Lebanese Public Administration reform is substantial. An efficient and effective mechanism to deal with change, development, and reform is the application of strategic planning. The aim of this paper is to shed the light on the influence of strategic planning on Lebanese public administration as a major concept for reform and development accompanied with the critical role played by Lebanese government to emphasis on the necessity to apply New Public Management reform culture. Adopting qualitative research method, the paper seeks to offer a wealthy literature about strategic planning and New Public Management and their role in public administration reform. In addition, quantitative research will take into consideration as an empirical study based on a questionnaire to recognize the perception of the Lebanese Ministry of State for Administrative Reform members' by analyzing five categories; institutional of strategic planning, setting up the strategic basis, strategic planning diagnosis, strategic planning development, and strategic planning implementation. Our findings will illustrate that the process of strategy and strategic planning have been neither documented precisely nor implemented adequately through almost all staffs, committees, and experts in the ministry. The results will contribute to enhance and improve the planning process by implementing a transparent strategic reform process along with New Public Management principles in order for the ministrv to reach its future mission. ambitions. and goals.
\end{abstract}

Keywords: Strategic Planning, Public Administration, New Public Management, Public Administrative Reform, Reform Strategy.

JEL classification: $\mathrm{H} 80, \mathrm{H} 83$

DOI: $10.24818 / \mathrm{RMCI} .2019 .3 .259$

\section{Introduction}

The development of societies in our contemporary world reflects the sustainable vision of governments to provide the best and most important services and activities through their public administrations bodies, such as healthcare, education, transportation, employment, security, etc. to meet and satisfy the need

\footnotetext{
${ }^{1}$ Charbel El Ammar ${ }^{1,}$ Bucharest University of Economic Studies'

Charbel.alammar@gmail.com
} 
and demand of public community (Labaki, 2015). To meet these goals, there is a strong need for a dramatically shift in the political, social, and economical life, which will be reflected by the immediate implementation of strategic plans and setting of clear strategic vision for the role played by Lebanese Public Administration in Lebanese society. Strategic planning is a method, a process for the functioning and performance of public administration. It's an approach used to manage resources, enhance public services, and meet community interest and satisfaction.

For many years, reform in public administration has not witnessed any significant plans for structural and operational development, thus resulting in inefficiency and ineffectiveness and that will ultimately lead to bad quality services, overlapping in responsibilities, inconsistencies in public policies, poor governance, and lack of transparency and accountability (Elsaad, 2001). Therefore, public administration reform has a considerable influence on social responsibilities and economic development of any nation.

Today, any reform strategy in public administration that does not take into consideration the procedures and methods of strategic planning in their development process will end up losing the opportunity to tackle the above mentioned shortcomings and that will affect directly and indirectly the stability and welfare of the community and above all the reliability and integrity of governments. In addition, New Public Management culture as a worldwide reform principle will boost Lebanese government to reconsider its performance by shifting from bureaucratic to entrepreneurial concept.

In Lebanon, the role of strategic planning in public administration reform is still within the range of coming and going, taking and responding, and "Ink on papers'. The lack of knowledge and culture on how to act and plan strategically in order to reform is the main reason why these issues should be under investigation and research to the extent of their influence on economy and social life.

\section{Literature Review}

Strategy is the invention of a distinctive attitude including varieties of actions and activities (Porter, 1996). Strategy sustains the existence of organizations through expecting and handling challenges arising from competition (Stewart, 2004). Plan for strategy is viewed as an accurate leadership object that is supported by legal control to assure its application and execution in a realistic environment (Mintzberg, 1994).

The seeds of strategic planning in public administration were first harvested in the military sector (Freedman, 2013). Yet, since 1960's, the evolution of ideas, techniques, concepts, and principles of strategic planning has appeared in private organizations. Stewart (2004) claimed that dealing with strategy in public administration is still modest. Compared to private models, strategy in public sector faced many constraints, even though, strategy suggests multiple benefits for public administration reform (Hughes, 2003). 
Strategy of the reform of public administration has been for many years a critical aspect for governments across nations (Pollit \& Bouckaert, 2004). Severe issues related to political influences, economic instability, and social complexities affect the ability to implement a reform strategy in public administration. Therefore, public administration is defying and challenging the pressure of an accurate and comprehensive reform strategy (Andrews, Downe, \& GuarnerosMeza, 2013). Thus, any strategy for reform entails a definite component of change.

Dealing efficiently and effectively with the wind of change requires from governments to apply the procedures and practices of strategic planning in public administration. Governments that have a transparent belief in strategic planning in public administration reform are further suitable for goal achievement. Today as the change hits our society and makes it more vulnerable to turbulent environment, the need for strategic thinking is essential for our organization sustainability and growth (Rainey, 2014).

Strategic planning is a measure to achieve an aim, an instrument adopted by organization to position itself with the availability of resources in an attempt to set organizational directions (Bryson, 1995). Bryson states that strategic planning is a road map of commitment and achievement that draw the arrow toward "what an organization is, what it does, and why it does it". Its objective is to boost strategic behavior, performance, and knowledge. Therefore, strategic planning shares future thought, literal interpretation, assessment of objectives and purposes, elaborate long term public administration, ensuring organization efficiency and effectiveness, and capability to fit community desires (Poister T. , 2010). Strategic planning is an approach of enhancing and developing the relationship between the organization and environmental change (Kotler, 2002). Strategic planning assists public administration to contemplate and react effectively to environmental change (Bryson, 1995).

The implementation of strategic planning is vital and reveals many benefits that lead organizations to react effectively within contemporary situations (Bryson \& Roering, 1998). Other scholars believe that the use of strategic planning may result in many advantages to a firm like the development of the organization vision and mission, setting and achievement of goals, analysis of internal strength and weaknesses and external opportunities and threats (Bryson, 1995). Strategic planning is a powerful mechanism to grasp opportunities for development and growth of an organization as well as a support for all employees at managerial level to have a unified purpose (Wheelen \& Hunger, 2012). In addition, public administration obtains several benefits when applying strategic planning; such as growing attention of essential stakeholders and political parties on goals, mission and vision of the state, as well as enhancing interaction across stakeholders, improvement in decision making and employee development, facing fluctuation in the environment, and above all improve organizational performance (Poister \& Streib, 2005).

The idea of strategic planning grown by private organizations in 1980's has begun to expand reaching the public sector as well as the communities and 
government organizations (Yosandi \& Wijaya, 2017). Several perspectives governed the implementation of strategic planning in public sector, yet most of them were placed at the corporate level of organization and were integrated in a distinctive appearance (Baile, 1998). In addition, an efficient implementation of strategic planning should attain certain measures such as it must be practically achievable, publicly and governmentally suitable and stand with the value of the organization (Bryson J. M., 1988).

According to Bryson (1988) the process of strategic planning follows a road of eight phases: starting with establishing a primary consent for strategic planning process, followed by, determination and illustration of mandates, and a well explained mission and vision, evaluation of the external forces of the environment, evaluation of the internal environment, identify the strategic situation, development of the strategy, and explanation of the future status of the organization. Furthermore, he assumes that performing the above mentioned phases of strategic planning process, public sector will be able to accomplish certain advantages like assisting firm directors to act in efficient manner and think strategically, design a creative and innovative firm vision, defeat supposed obstacles, establishing sustainable plans to overcome external threats, enhancing performance measurement, and react to any turbulence in the environment.

Experience a strategic planning process does not promise that public administration will accomplish its purposes and aims. Basically, the importance lies on the evaluation of the process and its relation with other managerial aspects applied in public administration (Leskaj, 2017).

Back to public administration reform, the most efficient tool to provide quality services and improve organizational performance and managerial efficiency in public administration is the implementation of New Public Management (Pollit, van Thiel, \& Homburg, 2007). Since its beginning in 1980's, a modern style of public administration reform took place in many nations that impose critical doubt on the standard aspects of public administration. The bureaucratic model of public administration which was implemented in the last century is turning to an adaptable and market based model (Hughes, 1998). That is New Public Management.

New Public Management is viewed as a worldwide improvement and reform act. It concentrates on growing efficiency and effectiveness in public administration by breaking the rules of modest form of administration and government control (Araujo, 2001). The ideology of New Public Management is intimately associated with concepts like public administration, privatization, and entrepreneurial act (Yosandi \& Wijaya, 2017). Fundamentally speaking, since 1980's US government started bureaucratic improvement and reform by applying privatization to carry on budgeting matters in providing quality services (Rodenbloom \& Mc.Curdy, 2006). The financial suffering encountered by the use of elderly bureaucracy has switched the vision on how to organize public administration better (Osborne, 1993). Also, Osborne (1993) stated that to face the change in the environment, public organization must be aware to the needs of citizens to react to environmental change and have the ability to promote 
sustainability. He contended that "public organization needs to be entrepreneurial rather than bureaucratic". At the entrepreneurial level, public organizations must be divided or integrated into well functioned business units in order to provide efficiency and effectiveness in service quality, implement private business models into public firms, have a transparent vision for employees duties and tasks, adapt a well-structured organization performance, and to be more concentrated on monitoring productivity (Hood, 1995). Further research has introduced five essential aspects that New Public Management must rely on entrepreneurial spirit and went further on reducing the spread of government activities; first of all by the use of privatization concepts, granting public sector industry to private sector one; second applying decentralization, made decision near the beneficiary of service; third downsizing, minimizing governmental scope; fourth de-bureaucratization, highlight on the importance of outputs rather than procedures, and fifth managerialism, act as business like. New Public Management is an innovative road of thinking administration reform (Hughes, 1998).

\section{Research Methodology}

The paper major aim represents a dual objective through examining and analyzing the reasons why the Ministry of State of Public Administrative reforms apply strategic planning as an executive and administrative instrument for rectification and reform, and recognizing if these strategic endeavor act as a main paradigm for change. Achieving the above mentioned objectives, the idea of strategic planning must be classified in five categories beginning by the institutional of strategic planning, setting up the strategic basis, and diagnosis of the strategic situation, strategic planning development, and strategic planning implementation. Also, the research objectives determine the method followed by strategic planning, leading to a more accountable administration and management, based on creating an efficient process with distinctive characteristics, an effective evolution on the application and development of procedures, plans, and performance and above all promoting transparency, efficiency, effectiveness, and contributing to improve the quality of community interest.

\section{Research Design and Instrument}

The design of the study clarifies its features and characteristics. The questionnaire contains both explanatory and exploratory signs consisting of data collected about strategic planning in Lebanese Ministry of State for Public Administrative Reform and its influence on multiple exponents of the Ministry performance. A 27 questions using numeric Likert scale from 1 to 5 are being used to collect data. As described in the research methodology the questionnaire is divided in 5 categories. In the first category of the questionnaire, data was collected linked to the institutional strategic planning, in the second category, data was collected linked to setting up the strategic basis, in the third category, data linked to 
the strategic planning diagnosis, in the fourth category data was collected based on strategic planning development, and the last category data was collected based on the implementation of strategic planning. Linking the outcomes with New Public Management reform, questions based on and related to the principles of New Public Management model were introduced in the third and fourth category of the questionnaire. Descriptive analysis of strategic planning was examined separately in each category by using SPSS version 22. Mean and standard deviation were calculated to measure the accuracy of the value of the data.

Institutional planning analyzed in 4 questions $(\mathrm{Q} 1 \rightarrow \mathrm{Q} 4)$

Setting up the strategic basis analyzed in 5 questions (Q5 $\rightarrow$ Q9)

Strategic Planning diagnosis analyzed in 8 questions $(\mathrm{Q} 10 \rightarrow \mathrm{Q} 17)$

Strategic planning development analyzed in 4 questions $(\mathrm{Q} 18 \rightarrow \mathrm{Q} 21)$

Strategic planning implementation analyzed in 6 questions $(\mathrm{Q} 22 \rightarrow \mathrm{Q} 27)$

\section{Study}

The study included members of the Lebanese Ministry of state for Administrative Reform with a total of 90 members distributed as follows: 40 members in Governmental Committees, 32 UNDP staffs, 11 governmental staff with contract, 6 European Union experts, and 1 governmental staff day laborer. An online questionnaire sent to the formal address of the Ministry of State for Administrative reform. The demand to reply was sent to the committee, staffs, and experts endorsed by the Ministry. From the 90 member, we obtained 60 replies from different members of committees, governmental staffs, experts, and UNDP staffs.

\section{Results and Discussions}

The purpose of the study is to answer the paper questions mentioned in the methodology. The questionnaire is analyzed based on Government committees, UNDP staffs, Governmental staffs, and European Union expert's responses. The answers lead the researcher to categorize the strategic planning steps in each category based on their viewpoints. Means and standard deviation under each category shed the light on the significance of each category and the level of contribution toward strategic planning.

1st Category - Institutional of Strategic Planning

Table 1 - Q1: The ministry takes legal responsibility of strategic planning.

\begin{tabular}{|l|r|r|r|r|}
\hline & Frequency & Percent & Valid Percent & \multicolumn{2}{|c|}{ Pumulative } \\
\hline Valid Strongly Disagree & 3 & 5.0 & 5.0 & 5.0 \\
Disagree & 30 & 50.0 & 50.0 & 55.0 \\
Neutral & 20 & 33.3 & 33.3 & 88.3 \\
Agree & 4 & 6.7 & 6.7 & 95.0 \\
Strongly Agree & 3 & 5.0 & 5.0 & 100.0 \\
Total & 60 & 100.0 & 100.0 & \\
\hline
\end{tabular}


Table 2 - Q2: Strategic planning is considered a priority in administrative reform in your ministry

\begin{tabular}{|l|r|r|r|r|}
\hline & & & \multicolumn{2}{|c|}{ Cumulative } \\
& Frequency & Percent & Valid Percent \\
\hline Valid Strongly Disagree & 2 & 3.3 & 3.3 & 3.3 \\
Disagree & 35 & 58.3 & 58.3 & 61.7 \\
Neutral & 15 & 25.0 & 25.0 & 86.7 \\
Agree & 3 & 5.0 & 5.0 & 91.7 \\
Strongly Agree & 5 & 8.3 & 8.3 & 100.0 \\
Total & 60 & 100.0 & 100.0 & \\
\hline
\end{tabular}

Table 3 - Q3: The ministry follows a clear methods and techniques in implementing the strategic planning and on regular basis

\begin{tabular}{|l|r|r|r|r|}
\hline & Frequency & Percent & Valid Percent & \multicolumn{2}{c|}{ Cumulative } \\
Valid Sercent
\end{tabular}

Table 4 - Q4: The members involved engage effectively in the strategic planning process

\begin{tabular}{|l|r|r|r|r|}
\hline & & & \multicolumn{2}{|c|}{$\begin{array}{c}\text { Cumulative } \\
\text { Percent }\end{array}$} \\
\hline Valid Strongly Disagree & 3 & 5.0 & 5.0 & 5.0 \\
Disagree & 32 & 53.3 & 53.3 & 58.3 \\
Neutral & 18 & 30.0 & 30.0 & 88.3 \\
Agree & 3 & 5.0 & 5.0 & 93.3 \\
Strongly Agree & 4 & 6.7 & 6.7 & 100.0 \\
Total & 60 & 100.0 & 100.0 & \\
\hline
\end{tabular}

Table 5: Descriptive Statistics

\begin{tabular}{|l|r|r|r|r|r|}
\hline & N & Minimum & Maximum & Mean & Std. Deviation \\
\hline Q1 & 60 & 1 & 5 & 2.57 & .890 \\
Q2 & 60 & 1 & 5 & 2.57 & .963 \\
Q3 & 60 & 1 & 5 & 2.50 & .893 \\
Q4 & 60 & 1 & 5 & 2.55 & .928 \\
Valid N (list wise) & 60 & & & & \\
\hline
\end{tabular}

Source: Authors' own research. 
In the 1 st category, table $1,2,3$, and 4 show the valid percentages by the number of respondents on each question from Q1 to Q4. We noticed that, 50\% of respondents do not agree with the idea that their ministry has a legal responsibility over strategic planning, $58.3 \%$ do not consider strategic planning as priority in administrative reform process, $61.7 \%$ stated that the ministry does not follow a clear methods and techniques in the implementation of strategic planning and on regular basis, and $53.3 \%$ of them do not engage effectively in the strategic planning process. As a result and based on the descriptive statistics, table 5 presents the average means of respondents based on the four questions. Every question has a value based on a scale from 1 to 5. Data shows that Q1 and Q2 possess the highest mean with a value of 2.57, followed by Q4 with an average mean of 2.55, then Q3 with an average mean of 2.50. These results illustrate that, in the first category, most respondents face a gap on the institutionalizing strategic planning phase and emphasize on the inconvenience results of the majority of respondents concerning the legal responsibility and aspect of strategic planning, the priority and importance of the planning as a platform for administrative reform, the procedures applied, and the effective involvement of members in charge for the implementation of the strategic planning process.

Institutionalizing the planning task is a crucial notion and thought in Ministry reform, the inability to institutionalize the planning behavior reduces the performance and efficiency of ministry work and its ability to change and reform (Saw \& Cummings, 1979).

2nd Category - Setting up the Strategic Basis

Table 6 - Q5: The ministry has a clear written mission

\begin{tabular}{|l|r|r|r|r|}
\hline & Frequency & Percent & Valid Percent & Cumulative Percent \\
\hline Valid Disagree & 2 & 3.3 & 3.3 & 3.3 \\
Neutral & 3 & 5.0 & 5.0 & 8.3 \\
Agree & 45 & 75.0 & 75.0 & 83.3 \\
Strongly Agree & 10 & 16.7 & 16.7 & 100.0 \\
Total & 60 & 100.0 & 100.0 & \\
\hline
\end{tabular}

Table 7 - Q6: The ministry has a transparent understanding of the mission

\begin{tabular}{|l|r|r|r|r|}
\hline & Frequency & Percent & Valid Percent & Cumulative Percent \\
\hline Valid Disagree & 5 & 8.3 & 8.3 & 8.3 \\
Neutral & 35 & 58.3 & 58.3 & 66.7 \\
Agree & 15 & 25.0 & 25.0 & 91.7 \\
Strongly Agree & 5 & 8.3 & 8.3 & 100.0 \\
Total & 60 & 100.0 & 100.0 & \\
\hline
\end{tabular}


Table 8 - Q7: Short and long term goals are well established and written by the ministry

\begin{tabular}{|l|r|r|r|r|}
\hline & Frequency & Percent & Valid Percent & Cumulative Percent \\
\hline Valid Strongly Disagree & 15 & 25.0 & 25.0 & 25.0 \\
Disagree & 25 & 41.7 & 41.7 & 66.7 \\
Neutral & 10 & 16.7 & 16.7 & 83.3 \\
Agree & 7 & 11.7 & 11.7 & 95.0 \\
Strongly Agree & 3 & 5.0 & 5.0 & 100.0 \\
Total & 60 & 100.0 & 100.0 & \\
\hline
\end{tabular}

Table 9 - Q8: The ministry goals are defined in terms of the objective of each ministry in the government

\begin{tabular}{|l|r|r|r|r|}
\hline & Frequency & Percent & Valid Percent & \multicolumn{2}{|c|}{ Percent } \\
\hline Valid Strongly Disagree & 15 & 25.0 & 25.0 & 25.0 \\
Disagree & 25 & 41.7 & 41.7 & 66.7 \\
Neutral & 10 & 16.7 & 16.7 & 83.3 \\
Agree & 7 & 11.7 & 11.7 & 95.0 \\
Strongly Agree & 3 & 5.0 & 5.0 & 100.0 \\
Total & 60 & 100.0 & 100.0 & \\
\hline
\end{tabular}

Table 10 - Q9: The goals are easy to be observed and measured using performance measurement and signals (NPM)

\begin{tabular}{|l|r|r|r|r|}
\hline & Frequency & Percent & Valid Percent & \multicolumn{2}{c|}{$\begin{array}{c}\text { Pumulative } \\
\text { Percent }\end{array}$} \\
\hline Valid Strongly Disagree & 10 & 16.7 & 16.7 & 16.7 \\
Disagree & 30 & 50.0 & 50.0 & 66.7 \\
Neutral & 12 & 20.0 & 20.0 & 86.7 \\
Agree & 5 & 8.3 & 8.3 & 95.0 \\
Strongly Agree & 3 & 5.0 & 5.0 & 100.0 \\
Total & 60 & 100.0 & 100.0 & \\
\hline
\end{tabular}

Table 11: Descriptive Statistics

\begin{tabular}{|c|c|c|c|c|c|}
\hline & $\mathrm{N}$ & Minimum & Maximum & Mean & Std. Deviation \\
\hline Q5 & 60 & 2 & 5 & 4.05 & .594 \\
\hline Q6 & 60 & 2 & 5 & 3.33 & .752 \\
\hline Q7 & 60 & 1 & 5 & 2.30 & 1.124 \\
\hline Q8 & 60 & 1 & 5 & 2.30 & 1.124 \\
\hline Q9 & 60 & 1 & 5 & 2.35 & 1.022 \\
\hline Valid N (list wise) & 60 & & & & \\
\hline
\end{tabular}

Source: Authors' own research 
In the 2 nd category, table $6,7,8,9$, and 10 show the valid percentages by the number of respondents on each question from Q5 to Q9. We noticed that, 75\% of respondents agree that the ministry has a clear written mission, while $58.3 \%$ of them have a neutral decision on whether or not the ministry has transparency on its mission, 25\% are insisting that the ministry does not have a well-established short term and long term goals, as well as the same percentage shows that these goals are not in in line with the objective of each ministry in the government, 50\% of respondents stated that these goals are not well observed and measured. As a result and based on the descriptive statistics, table 11 presents the average means of respondents based on the five questions. Every question has a value based on a scale from 1 to 5. Data shows that Q5 has the highest mean with a value of 4.05, followed by Q6 that possesses a mean with a value of 3.33, then Q9 with an average mean of 2.3, and lastly Q7 and 8 with an average mean of 2.30. Based on the average mean of these questions, we concluded that the most of respondents agree on the mission statement of the ministry in terms of promoting social and economic development, accountability, and transparency while contradict with the implementation of this mission in terms of short term and long term goals establishment as well as with the objective of seeking technical and development capabilities for ministries in assessing their change and reform, and in measuring and observing these goals based on signals and performance measures.

The advantage of setting up the strategic planning basis demonstrate the important awareness of all ministry members of mission statement, goals, and priorities and the ability of the ministry to set performance measurement standards and models in order for those goals to be observed and measured (Poister \& Streib, 2005). Build up a strategic planning help the ministry to develop its mission and vision, modification to the environment, and achieving short and long term goals (Bryson, 1995).

3rd Category - Strategic Planning diagnosis

Table 12 - Q10: The ministry has enough information about ministries, stakeholders and other related actors that influence its performance.

\begin{tabular}{|c|c|c|c|c|c|}
\hline & & Frequency & Percent & Valid Percent & $\begin{array}{l}\text { Cumulative } \\
\text { Percent }\end{array}$ \\
\hline \multirow[t]{6}{*}{ Valid } & Strongly Disagree & 5 & 8.3 & 8.3 & 8.3 \\
\hline & Disagree & 18 & 30.0 & 30.0 & 38.3 \\
\hline & Neutral & 17 & 28.3 & 28.3 & 66.7 \\
\hline & Agree & 13 & 21.7 & 21.7 & 88.3 \\
\hline & Strongly Agree & 7 & 11.7 & 11.7 & 100.0 \\
\hline & Total & 60 & 100.0 & 100.0 & \\
\hline
\end{tabular}


Table 13 - Q11: The ministry recognized the opportunities and threats in the environment and analyzes them.

\begin{tabular}{|ll|r|r|r|r|}
\hline & & & & Cumulative \\
& Frequency & Percent & Valid Percent & \multicolumn{1}{c|}{ Percent } \\
\hline Valid & Strongly Disagree & 8 & 13.3 & 13.3 & 13.3 \\
& Disagree & 2 & 3.3 & 3.3 & 16.7 \\
Neutral & 20 & 33.3 & 33.3 & 50.0 \\
Agree & 25 & 41.7 & 41.7 & 91.7 \\
Strongly Agree & 5 & 8.3 & 8.3 & 100.0 \\
Total & 60 & 100.0 & 100.0 & \\
\hline
\end{tabular}

Table 14 - Q12: The ministry makes self-assessment of its performance and operations.

\begin{tabular}{|ll|r|r|r|r|}
\hline & & & & Cumulative \\
& Frequency & Percent & Valid Percent & \multicolumn{1}{|c|}{ Percent } \\
\hline Valid & Strongly Disagree & 7 & 11.7 & 11.7 & 11.7 \\
& Disagree & 3 & 5.0 & 5.0 & 16.7 \\
Neutral & 24 & 40.0 & 40.0 & 56.7 \\
Agree & 20 & 33.3 & 33.3 & 90.0 \\
Strongly Agree & 6 & 10.0 & 10.0 & 100.0 \\
Total & 60 & 100.0 & 100.0 & \\
\hline
\end{tabular}

Table 15 - Q13: The assessment led the ministry to recognize its internal strengths and weaknesses.

\begin{tabular}{|ll|r|r|r|r|}
\hline & & & & Cumulative \\
& Frequency & Percent & Valid Percent & \multicolumn{2}{|c|}{ Percent } \\
\hline Valid & Strongly Disagree & 5 & 8.3 & 8.3 & 8.3 \\
& Disagree & 15 & 25.0 & 25.0 & 33.3 \\
& Neutral & 24 & 40.0 & 40.0 & 73.3 \\
Agree & 16 & 26.7 & 26.7 & 100.0 \\
Total & 60 & 100.0 & 100.0 & \\
\hline
\end{tabular}

Table 16 - Q14: Political interference affects the ministry analysis.

\begin{tabular}{|ll|r|r|r|r|}
\hline & & & & Cumulative \\
& Frequency & Percent & Valid Percent & \multicolumn{1}{c|}{ Percent } \\
\hline Valid & Disagree & 7 & 11.7 & 11.7 & 11.7 \\
& Neutral & 10 & 16.7 & 16.7 & 28.3 \\
& Strongly Agree & 43 & 71.7 & 71.7 & 100.0 \\
Total & 60 & 100.0 & 100.0 & \\
\hline
\end{tabular}


Table 17 - Q15: The ministry evaluate achievement of cost effectiveness (NPM)

\begin{tabular}{|ll|r|r|r|r|}
\hline & Frequency & Percent & Valid Percent & Cumulative Percent \\
\hline Valid & Strongly Disagree & 13 & 21.7 & 21.7 & 21.7 \\
& Disagree & 37 & 61.7 & 61.7 & 83.3 \\
Neutral & 7 & 11.7 & 11.7 & 95.0 \\
Agree & 3 & 5.0 & 5.0 & 100.0 \\
Total & 60 & 100.0 & 100.0 & \\
\hline
\end{tabular}

Table 18 - Q16: The ministry use privatization concept, contract, private and public cooperation to enhance quality of service and efficiency (NPM).

\begin{tabular}{|ll|r|r|r|r|}
\hline & Frequency & Percent & Valid Percent & Cumulative Percent \\
\hline Valid & Strongly Disagree & 37 & 61.7 & 61.7 & 61.7 \\
Disagree & 13 & 21.7 & 21.7 & 83.3 \\
Neutral & 8 & 13.3 & 13.3 & 96.7 \\
Agree & 2 & 3.3 & 3.3 & 100.0 \\
Total & 60 & 100.0 & 100.0 & \\
\hline
\end{tabular}

Table 19 - Q17: The ministry use strategic planning process in order to encourage competition (NPM).

\begin{tabular}{|ll|r|r|r|r|}
\hline & Frequency & Percent & Valid Percent & Cumulative Percent \\
\hline Valid & Strongly Disagree & 20 & 33.3 & 33.3 & 33.3 \\
& Disagree & 31 & 51.7 & 51.7 & 85.0 \\
Neutral & 5 & 8.3 & 8.3 & 93.3 \\
Agree & 4 & 6.7 & 6.7 & 100.0 \\
Total & 60 & 100.0 & 100.0 & \\
\hline
\end{tabular}

Table 20: Descriptive Statistics

\begin{tabular}{|l|r|r|r|r|r|}
\hline & $\mathrm{N}$ & Minimum & Maximum & Mean & Std. Deviation \\
\hline Q10 & 60 & 1 & 5 & 2.98 & 1.157 \\
Q11 & 60 & 1 & 5 & 3.28 & 1.121 \\
Q12 & 60 & 1 & 5 & 3.25 & 1.099 \\
Q13 & 60 & 1 & 4 & 2.85 & .917 \\
Q14 & 60 & 2 & 5 & 1.32 & .736 \\
Q15 & 60 & 1 & 4 & 2.00 & .850 \\
Q16 & 60 & 1 & 4 & 1.58 & .825 \\
Q17 & 60 & 1 & 4 & 1.88 & \\
Valid N (list wise) & 60 & & & & \\
\hline
\end{tabular}

Source: Authors' own research

In the 3rd category, the tables above show the valid percentage by the number of respondents of each question from Q10 to Q17. We noticed that, 30\% of respondents do not have enough information about ministries, stakeholders, and other factors that influence the ministry performance while in the same question Q10 21.7\% agree on the contrary (Table 12 ); 41.7\% recognized that the ministry perceive opportunities and threats in the environment and analyze them (Table 13);

$270 \quad$ Volume 20, Issue 3, July $2019 \quad$ Review of International Comparative Management 
$40 \%$ do not agree nor disagree in other word do not have any idea if the ministry make a self-assessment of its performance or not (Table 14); the same percentage applies for recognizing the strengths and weaknesses based on the assessment (Table 15). Political interference took the highest results among the majority of respondents by $71.7 \%$ (Table 16); cost effectiveness achievement that is considered one of the New Public Management principles is totally not met since $61.7 \%$ of respondents responses disagree with the ministry evaluation of cost (Table 17). Furthermore, considering NPM principles, $61.7 \%$ of responses see that the ministry does not use privatization concept or any public and private cooperation (Table 18). Also, encouraging competition with the private sector is not taking into consideration through the ministry internal operations since $51.7 \%$ of responses disagree with the question.

As a result and based on the descriptive statistics, table 20 presents the average means of respondents based on the eight questions. Every question has a value based on a scale from 1 to 5. Data shows that Q14 has the highest mean with a value of 4.32, followed by Q11 that possesses a mean with a value of 3.28, then Q12 with an average mean of 3.25, Q10 has an average mean of 2.98, Q13 has an average mean of 2.85, Q15 has an average mean of 2.00, and the last two question Q17 with an average mean of 1.88 and Q16 with an average mean of 1.58. Taking into consideration the average means, it took our attention that political interference is considered one of the most important factors that affect negatively the strategic planning process. Opportunities and threats are well recognized by the ministry but poorly assessed due to the incapability of the ministry to make a selfevaluation of its performance as well to its internal strengths and weaknesses. New Public Management reform principles concerning cost effectiveness, privatization, public and private partnership, and competition are poorly applied due to sharing power, authorities, and quotas among different political parties.

New Public Management appears as a reform pattern in public administration thinking and act (Hughes, 1998). The implementation of New Public Management reform principles in public sector is based on several models such as efficiency model; switching toward business like, decentralization, and downsizing, reform management model, encouraging the participation from low level to top level members in the change process, and public interest trend to reform, concentrating on advance quality of service to the community (Ferlie \& et al, 1996).

4th Category - Strategic Planning Development

Table 21 - Q18: The ministry follows a strategic thinking to formulate plans.

\begin{tabular}{|ll|r|r|r|r|}
\hline & & & & Cumulative \\
& Frequency & Percent & Valid Percent & \multicolumn{2}{c|}{ Percent } \\
\hline Valid & Strongly Disagree & 5 & 8.3 & 8.3 & 8.3 \\
& Disagree & 35 & 58.3 & 58.3 & 66.7 \\
Neutral & 3 & 5.0 & 5.0 & 71.7 \\
Agree & 17 & 28.3 & 28.3 & 100.0 \\
Total & 60 & 100.0 & 100.0 & \\
\hline
\end{tabular}

Review of International Comparative Management

Volume 20, Issue 3, July 2019 
Table 22 - Q19: The ministry assists in establishing a sustainable development strategy to overcome threats.

\begin{tabular}{|ll|r|r|r|r|}
\hline & Frequency & Percent & Valid Percent & $\begin{array}{c}\text { Cumulative } \\
\text { Percent }\end{array}$ \\
\hline Valid & Strongly Disagree & 8 & 13.3 & 13.3 & 13.3 \\
& 20 & 33.3 & 33.3 & 46.7 \\
& Disagree & 7 & 11.7 & 11.7 & 58.3 \\
Neutral & 25 & 41.7 & 41.7 & 100.0 \\
Agree & 60 & 100.0 & 100.0 & \\
Total & & & \\
\hline
\end{tabular}

Table 23 - Q20: The ministry examines R\&D alternatives to formulate and develop plans.

\begin{tabular}{|ll|r|r|r|r|}
\hline & & & & Cumulative \\
& Frequency & Percent & Valid Percent & \multicolumn{2}{c|}{ Percent } \\
\hline Valid & Strongly Disagree & 3 & 5.0 & 5.0 & 5.0 \\
& Disagree & 15 & 25.0 & 25.0 & 30.0 \\
Neutral & 22 & 36.7 & 36.7 & 66.7 \\
Agree & 19 & 31.7 & 31.7 & 98.3 \\
Strongly Agree & 1 & 1.7 & 1.7 & 100.0 \\
Total & 60 & 100.0 & 100.0 & \\
\hline
\end{tabular}

Table 24 - Q21: NPM principles are used in the formulation process.

\begin{tabular}{|ll|r|r|r|r|}
\hline & & & & Cumulative \\
& Frequency & Percent & Valid Percent & \multicolumn{2}{c|}{ Percent } \\
\hline Valid & Disagree & 20 & 33.3 & 33.3 & 33.3 \\
& Neutral & 35 & 58.3 & 58.3 & 91.7 \\
& Agree & 5 & 8.3 & 8.3 & 100.0 \\
Total & 60 & 100.0 & 100.0 & \\
\hline
\end{tabular}

Table 25: Descriptive Statistics

\begin{tabular}{|c|c|c|c|c|c|}
\hline & $\mathrm{N}$ & Minimum & Maximum & Mean & Std. Deviation \\
\hline Q18 & 60 & 1 & 4 & 2.53 & .999 \\
Q19 & 60 & 1 & 4 & 2.82 & 1.127 \\
Q20 & 60 & 1 & 5 & 3.00 & .921 \\
Q21 & 60 & 2 & 4 & 2.75 & .600 \\
Valid N (list wise) & 60 & & & & \\
\hline
\end{tabular}

Source: Authors' own research

In the 4th category, the tables above show the valid percentage by the number of respondents of each question from Q18 to Q21. We noticed the following: $58.3 \%$ of responses show that the ministry does not have a strategic thinking during the formulation of plans while $28 \%$ of them agree on the opposite (Table 21); in establishing a sustainable development strategy, 33\% of responses agree that the ministry is involved in sustainable development while $41.7 \%$ stated the opposite (Table 22); research and development concept to formulate plans took a neutral

$272 \quad$ Volume 20, Issue 3, July $2019 \quad$ Review of International Comparative Management 
results from $36.7 \%$ of responses while $31.7 \%$ do agree that research and development department play its role in the formulation process and $25 \%$ are disappointed by the question (Table 23); concerning New public management reform principles, we noticed that more half of the respondents do not have a clear understanding about what does it mean.

As a result and based on the descriptive statistics, table 25 presents the average means of respondents based on the four questions. Every question has a value based on a scale from 1 to 5. Data shows that Q20 has the highest mean with a value of 3.00, followed by Q19 that possesses a mean with a value of 2.82, then Q21 with an average mean of 2.75, and lastly Q18 with an average mean of 2.53. Based on the average means, we noticed that there is an accepted outcome that leads to follow a strategic thinking in formulating plans and establishing a sustainable development strategy to overcome threats arising from external environment, unawareness about New Public Management reform principles, as well as about Research and Development process.

5th Category - Strategic Planning Implementation Management

Table 26 - Q22: Strategic decision making is implemented based on the strategic plans.

\begin{tabular}{|ll|r|r|r|r|}
\hline & & & & Cumulative \\
& Frequency & Percent & Valid Percent & \multicolumn{2}{c|}{ Percent } \\
\hline Valid & Strongly Disagree & 2 & 3.3 & 3.3 & 3.3 \\
& Disagree & 38 & 63.3 & 63.3 & 66.7 \\
Neutral & 18 & 30.0 & 30.0 & 96.7 \\
Agree & 2 & 3.3 & 3.3 & 100.0 \\
Total & 60 & 100.0 & 100.0 & \\
\hline
\end{tabular}

Table 27 - Q23: Responsibilities are allocated for execution and implementation based on appropriate delegation.

\begin{tabular}{|ll|r|r|r|r|}
\hline & & & \multicolumn{2}{c|}{ Cumulative } \\
& & Frequency & Percent & Valid Percent & Percent \\
\hline Valid & Strongly Disagree & 11 & 18.3 & 18.3 & 18.3 \\
& 29 & 48.3 & 48.3 & 66.7 \\
& Disagree & 14 & 23.3 & 23.3 & 90.0 \\
Neutral & 6 & 10.0 & 10.0 & 100.0 \\
Agree & 60 & 100.0 & 100.0 & \\
Total &
\end{tabular}

Table 28 - Q24: Resources are allocated sufficiently for the application and implementation.

\begin{tabular}{|ll|r|r|r|r|}
\hline & & & & Cumulative \\
& & Frequency & Percent & Valid Percent & Percent \\
\hline Valid & Strongly Disagree & 10 & 16.7 & 16.7 & 16.7 \\
& 32 & 53.3 & 53.3 & 70.0 \\
& Disagree & 10 & 16.7 & 16.7 & 86.7 \\
Neutral & 8 & 13.3 & 13.3 & 100.0 \\
Agree & 60 & 100.0 & 100.0 & \\
Total &
\end{tabular}


Table 29 - Q25: Each phase of the plan has a measurable performance standard.

\begin{tabular}{|ll|r|r|r|r|}
\hline & & & & \multicolumn{2}{c|}{ Cumulative } \\
& Frequency & Percent & Valid Percent & \multicolumn{2}{|c|}{ Percent } \\
\hline Valid & Strongly Disagree & 8 & 13.3 & 13.3 & 13.3 \\
& Disagree & 22 & 36.7 & 36.7 & 50.0 \\
& Neutral & 30 & 50.0 & 50.0 & 100.0 \\
Total & 60 & 100.0 & 100.0 & \\
\hline
\end{tabular}

Table 30 - Q26: Strategic decision making is revised and data is monitored based on appropriate measurements.

\begin{tabular}{|ll|r|r|r|r|}
\hline & & & & \multicolumn{2}{c|}{$\begin{array}{c}\text { Cumulative } \\
\text { Percent }\end{array}$} \\
\hline Valid & Strongly Disagree & 7 & 11.7 & 11.7 & 11.7 \\
& Disagree & 25 & 41.7 & 41.7 & 53.3 \\
& Neutral & 25 & 41.7 & 41.7 & 95.0 \\
Agree & 3 & 5.0 & 5.0 & 100.0 \\
Total & 60 & 100.0 & 100.0 & \\
\hline
\end{tabular}

Table 31 - Q27: Members in charge of strategic implementation are being rewarded based on their effective performance.

\begin{tabular}{|ll|r|r|r|r|}
\hline & Frequency & Percent & Valid Percent & Cumulative Percent \\
\hline Valid & Strongly Disagree & 10 & 16.7 & 16.7 & 16.7 \\
& Disagree & 45 & 75.0 & 75.0 & 91.7 \\
Neutral & 5 & 8.3 & 8.3 & 100.0 \\
Total & 60 & 100.0 & 100.0 & \\
\hline
\end{tabular}

Table 32: Descriptive Statistics

\begin{tabular}{|c|c|c|c|c|c|}
\hline & $\mathrm{N}$ & Minimum & Maximum & Mean & Std. Deviation \\
\hline $\mathrm{Q} 22$ & 60 & 1 & 4 & 2.33 & .601 \\
\hline Q23 & 60 & 1 & 4 & 2.25 & .876 \\
\hline Q24 & 60 & 1 & 4 & 2.27 & .899 \\
\hline Q25 & 60 & 1 & 3 & 2.37 & .712 \\
\hline Q26 & 60 & 1 & 4 & 2.40 & .764 \\
\hline Q27 & 60 & 1 & 3 & 1.92 & .497. \\
\hline Valid N (list wise) & 60 & & & & \\
\hline
\end{tabular}

Source: Authors' own research

In the last category, which is about the strategic planning implementation management, the tables above show the valid percentage by the number of respondents of each question from Q22 to Q27. Table 26 indicates that $63.3 \%$ of participants stated that the ministry does not possess a strategic decision making process based on the strategic plans while $30 \%$ of them have a neutral opinion; Table 27 shows that $48.3 \%$ of responses do not have any responsibilities based on the delegation of implementing the plans; $53.3 \%$ assure that resources are not sufficiently allocated for the implementation of the strategic plans (Table 28); 50\%

274 Volume 20, Issue 3, July $2019 \quad$ Review of International Comparative Management 
of participants do not have an idea about performance measurements standard while $36.7 \%$ of them stated that there is no existence of those standards (Table 29). Monitoring data and revision of strategic decision making based on appropriate measures result in equality responses $41.7 \%$ for both unaccepted and neutral (Table 30 ); $75 \%$ of respondents responses indicates that reward programs are not being implemented based on the appropriate performance (Table 31).

As a result and based on the descriptive statistics, table 32 presents the average means of respondents based on the six questions. Every question has a value based on a scale from 1 to 5. Data shows that Q26 has the highest mean with a value of 2.40, followed by Q25 that possesses a mean with a value of 2.37, Q22 with an average mean of 2.33, Q24 with an average mean of 2.27, Q23 has an average mean with a value of 2.25 , and Q27 with a mean of 1.92. Unable to take consideration rewarding members in charge for the implementation process will result a weak performance among employees and managers which lead them to allocate resources based on their own objectivity. Without considering the measurements standards, data monitoring and strategic decision making revision will definitely be inadequate and inconvenient due to discrepancy in situations. Solving these issues, strategic planning highlights on five essential aspects in public administration, starting with supporting and encouraging members to think strategically, decision making improvement, public administration improvement, improvement in resource allocation and outcomes within public administration, and rewarding all members of public administration in charge of implementing strategic planning (Bryson, 1995).

\section{Conclusion}

Until today, the Lebanese government continues to suffer from the consequences of the war that destroyed our country and led to the collapse of the society and the division of the country between sects. This led to demolishing the values of the state and strengthened the control of the sects and political parties, legislation of corruption, giving priority to the private interest of each party instead of the public interest of the community, and above all loss of strategies in various systems and state management. Today as the wind of change hits our society, and in order for Lebanon, people and government, to fulfill its promises and future obligations in face of the international community prior to the implementation of Cedar conference, an efficient and effective strategic planning model must be applied.

The purpose of the study contributes to enlighten on the importance of strategic planning on the reform of Lebanese public administration in order to organize, enhance, and improve the planning process. The results of the questionnaire confirmed that the implementation of strategic planning in Lebanese Ministry of State for Administrative Reform faces a huge gap on almost all categories of the strategic planning process and must be rectified. 
The outcomes and conclusions of the questionnaire analysis must be addressed as follow:

- The initiation and institutional function of strategic planning in Lebanese Ministry of State for Administrative Reform should be cultivated not only in members mind but also in their spirit shifting the ministry form its current position to a progress situation resulting on taking legal responsibilities, setting priorities and procedures, and motivating ministry members to act efficiently and effectively in the strategic planning process.

- Install transparency, accountability, and credibility in members mind as well as the strategic thinking based on a clear and understandable mission and vision. Setting observable and measurable goals.

- Defining and explaining the principles of New Public Management across ministry members, and encouraging minster to take the initiatives act and motivate public administrative bodies to switch from bureaucratic process to entrepreneurial process.

- Encourage the application of privatization and the partnership between both public and private sector in order to reduce the ability of government authorities to allocate resources based on their political and sectarian trends.

- Manage and organize budgeting and cost, by fighting corruption and develop transparent plans for financial spending.

- The ministry must conduct SWOT analysis in order to identify its internal strengths and weaknesses and external opportunities and threats and evaluate based on the interest of the society and to promote better service quality.

- Strategic plans must be sustainably developed to meet social, economic, and environmental aspects. One of the most important methods in today strategic thinking is sustainability.

- Support Research and development models that lead to create an innovative thinking by either enhancing and improving current services or developing new ones.

- Lebanese Ministry of Administrative Reform should stay aware to the implementation of strategic planning by ensuring that decision making is made based on the strategic plans.

- Resources and responsibilities are allocated sufficiently and effectively resulting in the raise of work efficiency.

- Setting performance measurements standards based on each phase of the strategic plans.

- Reward system must be adopted based on member's performance.

The limitations of the study is that it is not applicable to all ministries and government agencies, yet, it is applicable only on one sample, the Lebanese Ministry of Administrative Reform, so the research must be extended to cover and study more ministries and government bodies and their connection between each other by adopting a coherent strategic thinking that pave the road for an innovative strategic reform model adopted among Lebanese government to achieve the state mission, ambitions, and dreams. 


\section{References}

1. Andrews, R., Downe, J., \& Guarneros-Meza, V. (2013). Public Management Reform and Social Cohesion n Europe: An Empirical Analysis' . Retrieved December 12, 2015, from http://www.cocops.eu/wpcontent/uploads/2013/12/Deliverables-6.1.pdf

2. Araujo, J. (2001). Improving Public Service Delivery: The Crossroads Between NPM and Traditional Bureacracy. Public Administration, Vol. 79, p. 4.

3. Baile, C. (1998). A Study of Strategic Planning in Federal Organizations (Dissertation). Faculty of the Virginia Polytechnic Institute and State University.

4. Bryson, J. (1995). Strategic Planning for Public and NonProfit Organizations: A Guide to strengthening and Sustaining Organizational Achievment, Rev.ed. San Francisco: Jossey Bass.

5. Bryson, J. M. (1988). A strategic Planning Process for Public and Non-Profit Organizations. Long Range Planning, Vol. 21 (1), 73-81.

6. Bryson, J., \& Roering, W. (1998). Initiation of strategic Plannig by Governments',Public Administration Review, 1998. vol. 48, no. 2, pp. 9951004.

7. Elsaad, F. (2001). Strategy For the Reform and Development of the Public Administration in Lebanon. Beirut: Office of the Minister of State for Administrative Reform.

8. Ferlie, E., \& et al. (1996). The New Public Management in Action. New York: Oxford University Press.

9. Freedman, L. (2013). Strategy: A History. New York: Oxford University Press.

10. Hood, C. (1995). The "New Public Management" in the 1980's: Variations on a Theme. Accounting, Organizations and society, Vol. 20 (2/3), 93-109.

11. Hughes, O. (1998). Public Management and administration: An Introduction. London: Macmillan Press Ltd.

12. Hughes, O. (2003). Public Management and Administration: An Introduction, 3rd Edition. Melbourne: Macmillan.

13. Kotler, P. (2002). Marketing Management. Informator, Zagreb: Croatian Translation.

14. Labaki, G. (2015). The Reform of the Lebanese Public Administration in the framework of the Changing role of the State. Army Magazine.

15. Leskaj, E. (2017). The Challenges Faced by the Strategic Management of Public Organizations. Administratie si Management Public, (29), pp. 151-161.

16. Mintzberg, H. (1994). The Rise and Fal of Strategic Planning: Reconceiving Roles for Planning, Plans, Planners. New York: Free Press.

17. Osborne, D. (1993). Reinventing Government. Public Productivity and Management Review, vol.16 (4), pp. 349-356. 
18. Poister, C., \& Streib, G. (2005). Elements of strategic Planning and Management in Municipal Government: Status after Two Decades, 2005. Public Administration Review, vol. 65, no. 1, pp.45-46.

19. Poister, T. (2010). The Furue of Strategic Planning in the Public Sector: Linking Strategic Management and Performance. Public Administration Review.

20. Pollit, C., \& Bouckaert, G. (2004). Public Management Reform: A Comparative Analysis, 2nd ed. Oxford: Oxford University Press.

21. Pollit, C., van Thiel, S., \& Homburg, V. (2007). New Public Management in Europe: Adaptations and Alternatives. Basingstoke: Palgrave MacMillan, 2007.

22. Porter, M. (1996). What is Startegy? Harvard Business Review, pp.61-78.

23. Rainey, H. (2014). Understanding and Managing Public Organization, 5th edition. San Francisco: Jassey Bass, 2014.

24. Rodenbloom, D., \& Mc.Curdy, H. (2006). Revisiting Waldo's Administrative State: Constancy and Change in Public Administration. Washington DC: Georgetown University Press, pp. 151-178.

25. Saw, B., \& Cummings, L. (1979). Research in Organizational Behavior. Greenwich, CT: JAI Press.

26. Stewart, J. (2004). The Meaning of Strategy in the Public Sector. Australian Journal of Public Administration.

27. Wheelen, T., \& Hunger, J. (2012). Strategic Management and Business Policy: Towards Global Sustainability. USA: Pearson.

28. Yosandi, Y., \& Wijaya, A. (2017). Strategic Planning Adoption in Public Organization in Indonesia. Jurnal Ilmiah Administrasi Publik, vol. 3, no. 3, pp. 261-268. 